\title{
Corporate Governance and Board of Directors Responsibility in Appointing Senior Managers: A Case in Saudi Arabia
}

\author{
Ayman Mohamed Zerban ${ }^{1}$ \& Abdullah Mohammed Abdullateef Madani ${ }^{2}$ \\ ${ }^{1}$ Accounting Department, College of Business Administration, University of Business and Technology, Jeddah, \\ Saudi Arabia \\ ${ }^{2}$ General Department, College of Business Administration, University of Business and Technology, Jeddah, \\ Saudi Arabia
}

Correspondence: Ayman Mohamed Zerban, Accounting Department, College of Business Administration, University of Business and Technology, Jeddah, Saudi Arabia. E-mail: ayman@ubt.edu.sa

Received: September 29, 2017

doi:10.5539/ijbm.v13n1p183
Accepted: November 18, 2017 Online Published: December 20, 2017

URL: https://doi.org/10.5539/ijbm.v13n1p183

\begin{abstract}
Corporate governance is a cornerstone in improving efficiency and creating confidence to attract investors. After collapses of giant companies, worldwide business community are trying to infuse a culture of honesty and integrity in business. Commitment of board of directors and willing of top management and employees to strength corporate governance is essential. Failure to compliance with corporate governance rules will increase operational risk and hence impacting interests of stakeholders.

Saudi Arabian Monetary Agency (SAMA) which is the central bank in the Kingdom of Saudi Arabia with Capital Market Authority (CMA) are thriving continuously to strength corporate governance rules for banks and financial institutions. One of the circulars for banks and financial institutions is the requirements for appointments of senior positions in financial organizations with the objective of appointing persons who possess integrity, honesty, and good reputation. Companies should obtain written non-objection form for the appointment of senior managers and it is the responsibility of board of directors to ensure compliance with this regulation. In addition, SAMA issued several guidelines for anti-money laundering, rules for countering fraud and a code of professional ethics of staff. Recently, banks are required to form compliance unit to make sure banks prepare their financials according to International Financial Reporting Standards (IFRS).

The aim of this paper is to highlight a case of corporate governance and board responsibilities in one of the financial institutions in Saudi Arabia. The case will be presented to show the mechanism followed by the financial institution and whether it is complied with rules in appointing senior managers and if not what corrective actions are done in order to strength corporate governance principles.
\end{abstract}

Keywords: Board of director's responsibilities; Saudi Arabian Monetary Agency, Corporate Governance

\section{Introduction}

Corporate governance had gain popularity nowadays specially after the collapses of many companies who appeared giant and efficient while actually they were fragile. Expropriation of stakeholders by senior managers is widely evident with the collapses of companies such as Enron which is symbolic of shareholders failure to protect their interests due to asymmetrical information and conflict of interest in board of directors (Heath and Norman, 2004). The inefficiency of corporate governance mechanisms in banks and financial institutions are blamed in each crises. However, after absorbing the impact of failure, many opinions call for re-designing corporate governance mechanisms to ensure board responsibility, accountability, risk management, transparency and disclosure in financial reports (Jensen, 2002). Despite the negative impact of Enron collapse, the case "has done for reflection on corporate governance what AIDS did for research on the immune system" (Norman, 2004). The ties between executive managers and shareholders were destroyed because of manager's greed and willingness to benefit themselves over shareholders interest. Although shareholders should be supported by board and have a special position in the front line of interest to managers as providers of capital, sometimes board of directors do not choose to act and other times were myopic. Ibid (2004, p.6) states:

Boards of Directors often conspired with the executives (because the executives and their friends sat on the 
Board, controlling the agenda and directing important committees), or failed to exercise sufficient diligence in monitoring the executives; the shareholders, especially large institutional shareholders, paid insufficient attention to the quality of the Boards and to the reports of external auditors.

According to stakeholders' theory, managers should make decisions that are in the best interest of stakeholders. However, Jensen (2002) criticizes the ability of managers to satisfy all stakeholders at the same time and in this case the theory is "unassailable" (Ibid, 2002, p.241). As when a manager is trying to maximize shareholders wealth, current profits, market share, future growth in profits can destroy his ability to take the right decision. As "A manager directed to maximize both profit and market share has no way to decide where to be in the range between maximum profits and maximum market share" (Ibid, 2002, p.238). Managers under the supervision of the board should take all different dimensions in mind for the well-being of the firm and welfare of society. It is necessary to have internal control system to limit managerial actions. He states (p.242):

Because stakeholder theory provides no criteria for what is better or what is worse, it leaves boards of directors and executives in firms with no principled criterion for problem solving ... it leaves managers and directors unaccountable for their stewardship of the firm's resources. With no criteria for performance, managers cannot be evaluated in any principled way. Therefore, stakeholder theory plays into the hands of self-interested managers allowing them to pursue their own interests at the expense of society and the firm's financial claimants.

The size and magnitude of Enron's failure challenges academic beliefs about the role that could be played by board of directors. The aligning of manager's interests with stakeholder's interests need more solid foundations other than assuming that it is easily being aligned. Enron highlighted the way in which loose regulations had led auditors to allow accounting methods that promote overstating profits while analysts remained positive and sometimes silent in spite of un-logical financial results. The changes in executive compensation in the 1990s in USA, designed to align executive interests with those of shareholders, provided a strong incentive to managers to overstate earnings, even if this was not sustainable and illusionary. When chief executive officers spend three to four years in companies and cash their stock options and then markets are not quick to respond then stakeholders face the consequences (Clarke, 2005; Coffee 2004).

Board of directors should play different roles in organizations in order to maintain their sustainability. They have to plan strategic direction, advising, active monitoring and disciplining roles. Also the board should control the process of appointing executives and assessing their actions. Adams et al., (2010, p.65) state:

Assessment can be seen as having two components, one is monitoring of what top management does and the other is determining the intrinsic ability of top management. The monitoring of managerial actions can, in part, be seen as part of a board's obligation to be vigilant against managerial malfeasance. Yet, being realistic, it is difficult to see a board actually being in a position to detect managerial malfeasance directly; at best, a board would seem dependent on the actions of outside auditors, regulators, and, in some instances, the news media. Indirectly, a board might guard against managerial malfeasance through its choice of auditor, its oversight over reporting requirements, and its control over accounting practices.

This research proceeds as follows. Section two, is going to explain responsibility of board of directors in appointing and monitoring managers. Thirdly, the case of one of financial institution in the Kingdom of Saudi Arabia is presented. The fourth section, discusses whether the board of directors fulfill their responsibilities by adhering to corporate governance rules of appointing senior executives and if not what corrective actions are done in order to strength corporate governance principles. Finally, fifth section is a conclusion and recommendations for the paper.

\section{Responsibility of Board of Directors in Appointing and Monitoring Managers}

In many countries shareholders have a dominant role in appointing board of directors. Shareholders believe that appointed board and senior managers will act in their interests. Senior managers are responsible of directing, planning and controlling work and take corrective actions necessary. They should manage risk, have appropriate control systems, provide accurate information and act ethically. Shareholders place their trust in board's decisions in supervising senior manager's actions and proficiency. However, in many incidents this is not the case and agency problem persist. When existing and potential investors are considering buying or selling stocks of any companies, they often rely on financial information which is not forward looking, subjective and sometimes incorrect. In this case, shareholders confidence for an effective role and responsibilities of the board in supervising and selecting senior managers is crucial. In order for corporate governance to function efficiently, several dimensions might be taken into consideration including role and responsibilities of the board, board composition, management process, relationship between board members, and duality of CEO and Chairman (Jan and Sangmi, 2016). Güner et al., (2008) conducted a study covering 282 companies over 14 years to explore 
board composition when appointing financial expertise and the conflicts of interest due to commercial bank and investment bank affiliation. They argued the financial expertise tend to benefit their own banks by giving loans instead of increase shareholders value in companies who are part of their board. Firms and policy makers should think again about increasing financial expertise in board of directors if they are going to make shareholders' interests as second priority.

The roles and responsibilities of a board of directors are different, depending on the nature and type of organization and the laws applied in a certain country. Similarly, the establishment of different committees is a means to channel the functions of a board into expertise groups of directors that focus on specific issues in organization. The role of the board is critical for the success of companies. According to UK Corporate Governance Code (2016), the board should make sure that financial and human are available to fulfil companies objectives. The board is responsible for making sure an amalgam of skills and experience is present for running companies smoothly and efficiently (Gibbon et al., 2017). The role of the board had changed from passive role to become more active in monitoring and disciplining managers while overseeing their actions. They have evolved from "managerial rubber-stamps to active and independent monitors", thus allowing more effectiveness for corporate governance (Adams et al., 2010, p.64). Kaplan and Bernadette (2006) examine all Fortune 500 firms during period from 1991-2005 to determine CEO turnover internally through board driven or externally through takeover or bankruptcy. They state (p.2, emphasis added):

Annual CEO Turnover is $14.9 \%$ from 1992 to 2005, implying an average tenure as CEO of less than seven years. In the more recent period since 1998, total CEO turnover increases to $16.5 \%$, implying an average CEO turnover of just over six years. Internal or board driven turnover also rises substantially, increasing from $10.3 \%$ in the first part of the sample to $\mathbf{1 2 . 8 \%}$ in the latter part of the sample.... previous work suggests a modest relation between internal (board initiated) turnover and firm performance ..... We find a stronger and significant relation between internal turnover and firm performance.

Corporate governance can be viewed as a nexus of relations between board of directors, company management, shareholders, debtholders, customers, government and other stakeholders within a social, legal and political framework. The effectiveness of corporate governance flourish in an environment of compliance, transparency and accountability. Board of directors has a control, strategic and resource provision roles. The supervisory board "can help the firm connect with the relevant segments and environmental constituencies" (Tomsic, 2012, p.74). Isik and Ince (2016) argued that board of directors is a cornerstone in the governance mechanism. Different critical areas should be taken into consideration by the board such as emphasizing ethical values, standards in the work environment and overseeing strategies that address sustainability and stakeholder interests. Bernardi and LaCross (2005) surveyed a sample of quarter of Fortune 500 companies in order to explore their concern about publishing their codes of ethics to strength corporate governance. They discovered, that since the collapse of Enron in 2002, companies generally give increasing emphasis to code of ethics, which can be seen as a positive sign. There were also no significant differences in the disclosure rates between different industries. One astonishing finding was that in 2002 none of the former companies audited by Arthur Andersen revealed ethics policies on their websites. Fung (2014) argued for the need of board of directors to monitor and control senior manager's performance. He (p.73, emphasis added) states:

Corporate governance highlights the important principles of oversight and control over the executive management's performance and strategic directions; and their accountability to the shareholders. A code of ethics, which clarifies and stipulates adherence to some of more abstract ideals of trust and accountability, is essential for good corporate governance. The board and management should endeavor to uphold and nurture accountability, transparency, fairness, and integrity in all aspects of the company operations.

Onetto (2007) argued that two agency problems exists one where the board is the agent for shareholders and at the same time assumed to be principal to directors. The board monitors management on behalf of its principals shareholders, and trying to monitor and deduct managerial inefficiency and abuse. Sometimes managers have power over the board as it manifested in Enron. He states (p.416):

A board's independence depends on a bargaining game between the board and the CEO ... Of the many responsible parties implicated in Enron's scandal, it could be said that the board's inactions, up to a certain extent, led the company to its demise in December 2001. Enron's board approved a disclosure policy that made the firm's financial results substantially opaque to public capital markets. It also approved a compensation strategy that made managerial payoffs highly sensitive to stock price changes and it also failed to engage in an intense monitoring of business results and financial controls.

In Saudi Arabia, The General Department of Finance is in charge of controlling the financial sector and has the 
authority to supervise the activities of finance companies according to Finance Companies Control Law (2016). Although rules and regulations are available, monitoring implementation is necessary when managers and board try to manipulate it whether intently or by ignorance and this will be the concern of the case going to be presented.

\section{3. $X$ Financial Institution and Board Responsibilities}

Corporate governance regulation has been issued by Capital Market Authority (CMA) in November 2006, in response for Saudi Stock market crash. However, corporate governance in Saudi Arabia is still a fairly new concept, the Saudi Arabian Monetary Agency (SAMA) and Capital Market Authority (CMA) are still in the process of organizing the financial markets and highlighting the benefits of applying good corporate governance and many of the laws and institutions are still relatively new with little experience; awareness of the importance of good corporate governance is low, and implementation by companies is in its early stages (Al-Matari et al., 2012).

The Saudi Arabian Monetary Agency (SAMA), the central bank of the Kingdom of Saudi Arabia, has been entrusted with performing many functions. The most important two of those functions are: licensing financial institutions to operate in the kingdom financial sector and supervise those finance institutions' activities in accordance with the following rules and regulations:

- Real Estate Finance Law issued with the royal decree Number $\ 50,13 \backslash 08 \backslash 1433 \mathrm{H}$ (Islamic year), and its implementing regulations number 1229 issued on $10 \backslash 04 \backslash 1434 \mathrm{H}$.

- Finance Lease Law issued with the royal decree Number $48,13 \backslash 08 \backslash 1433 \mathrm{H}$, and its implementing regulations issued on $14 \backslash 04 \backslash 1434 \mathrm{H}$.

- Finance Companies Control Law issued with the royal decree Number $151,13 \backslash 08 \backslash 1433 \mathrm{H}$, and its implementing regulations issued on $14 \backslash 04 \backslash 1434 \mathrm{H}$.

The General Department of Finance is in charge of controlling the financial sector and has the authority to supervise the activities of finance companies, including the following:

- Extend license to engage in one or more finance activities (there are currently 47 financial institutions licensed to operate in the kingdom);

- Take necessary measures for maintaining the integrity and stability of the finance sector and fairness of transactions;

- Take necessary measures for promoting fair and effective competition between finance companies;

- Issue required rules and instructions to regulate the finance sector; and

- Take proper means for the development of the finance sector, Saudization, and raising the employees' competency through regulating the obligations of the finance companies regarding the training of human resources, improving their skills and developing their knowledge.

Our concern is one of the financial institution supervised by SAMA that has failed to undertake the necessary measurements to comply with some of SAMA regulations. The company name and person's names have been altered for privacy purposes. We will call it X Company which singed on $20 \backslash 6 \backslash 1435 \mathrm{H}$ an acknowledgment and pledge form in which clause (5) reads "the company shall have in independent department or a position to deal solely with the compliance obligations by $13 \backslash 1 \backslash 1436 \mathrm{H}$ ". SAMA off-site team conducted a supervisory visit on the company's premise on $09 \backslash 11 \backslash 1435 \mathrm{H}$, and noticed that the company had assigned a Jordanian national named Mr. CCC to handle the obligations of the compliance officer without requesting SAMA's non- objection form. Note that the company on the acknowledgment and pledge form also pledged to hire two compliance officers in the compliance department before the implementation of the finance companies control law takes effect. On the second supervisory visit to the company's premise on $22 \backslash 10 \backslash 1436 \mathrm{H}$, the off-site team noticed that Mr. CCC was Still assigned to handle the obligations of a compliance officer without requesting SAMA's non- objection form.

The company later updated its data of the occupiers of the leadership positions and inserted Mr. CCC as the assigned compliance officer and attached his certified "fit and proper form" to SAMA's license division without obtaining SAMA's non- objection form to his assignment as it is required according to the implementing regulation of the finance companies control law. SAMA sent an official letter number $(000)$ on $18 \backslash 3 \backslash 1437 \mathrm{H}$ to the company's CEO Mr. BBB requesting a statement to address the justifications of the company's failure to comply with clause (1) of article (42) of the implementing regulation of the finance companies control law and article (5) of the above mentioned acknowledgment and pledge form. On $18 \backslash 03 \backslash 1437 \mathrm{H}$, SAMA received a letter from Mr. BBB stating that the company did comply with clause (1) of article (42) of the implementing regulation of the 
finance companies control law and clause (5) of the acknowledgment and pledge form because a position to deal solely with the compliance obligations was established since October 2014, and the officer reports directly to the audit committee whose recommendations regarding compliance reports are submitted to the board of directors. $\mathrm{He}$ also stated that the separate position to deal solely with the compliance obligations was occupied by an assigned employee who is on probation and does nothing except dealing solely with the compliance obligations since the day of his assignment. Moreover, they are currently considering appointing him full time for the compliance officer's position after a year passes to his assignment.

On $19 \backslash 03 \backslash 1437 \mathrm{H}$, Mr. SSS from the internal examination division at SAMA notify the company that SAMA has not yet received a formal request to obtain SAMA's non- objection form to place Mr. CCC on the position of the assigned compliance officer and therefore, the company is in violation of article (1) of the requirements for appointments of senior positions in financial institutions supervised by SAMA.

In the responded letter received from Mr. BBB on $19 \backslash 03 \backslash 1437 \mathrm{H}$, he stated that it was an un-intentional mistake the company has made and he promised to take the necessary measurements immediately to fix this un-intentional mistake. On $20 \backslash 03 \backslash 1437 \mathrm{H}$, SAMA received a formal request from the company to appoint Mr. CCC Officially to the compliance officer's position.

According to rules and regulation, Article (1) of the Finance Companies Control Law senior management includes: "The managing director, chief executive officer, general manager, their deputies, the chief financial officer and heads of major departments, in addition to risk management, internal audit and compliance officers in the finance company". The requirements for appointments to senior positions in financial institutions supervised by SAMA issued in 1434H states that (Saudi Arabian Monetary Agency, 1434H).

- Clause (9) Candidates for senior positions shall not assume the charge of their respective roles until receipt of a written non-objection from SAMA.

- Clause (11) The financial institution is required to obtain SAMA's written non-objection prior to reassigning responsibilities of a senior position to any of its employees for a period exceeding (30) days, provided that the period of such reassignment does not exceed (6) months which can be renewed for another period after SAMA's approval.

Article (41) of the Regulation of the Finance Companies Control Law "The finance company shall comply with applicable laws, regulations and instructions and shall take necessary measures and controls to prevent violations."

Article (45) of the Regulation of the Finance Companies Control Law "The compliance department must have staff and resources commensurate with the business model and size of the finance company. Compliance employees shall report solely to the compliance officer."

Article (76) of the Regulation of the Finance Companies Control Law "A violation of the provisions of the Law and Regulation or non-compliance with any of the rules or instructions issued by SAMA shall be deemed a professional misconduct".

The following section discusses whether the board of directors fulfill their responsibilities by adhering to corporate governance rules of appointing senior executives and if not what corrective actions are done by Saudi Arabia Monetary Agency (SAMA) in order to address the violation to corporate governance principles as addressed in Finance Companies Control Law.

\section{Discussion}

Board of directors is the cornerstone in effective corporate governance. Efficient roles and responsibilities for the board with commitment to comply with rules and regulation can help in creating value and protect interests of stakeholders. The position of compliance officer is a senior management position that is considered to be one of the leadership roles in financial companies as it was articulated in the definitions section in the first article of the Finance Companies Control Law. Assigning Mr. CCC to handle the obligations of the compliance officer required from the company an obtainment of a written non-objection from SAMA as the requirements for appointments to senior positions in financial institutions. Also, the requirement number (11) of this same regulations stated" The Financial Institution is required to obtain SAMA's written non-objection prior to reassigning responsibilities of a senior position to any of its employees for a period exceeding (30) days, provided that the period of such reassignment does not exceed (6) months which can be renewed for another period after SAMA's approval" (Saudi Arabian Monetary Agency, 1434H).

Moreover, the company's CEO in his letter received on $18103 \backslash 1437 \mathrm{H}$ confessed that the duties and obligations of 
this senior management position was assigned to Mr. CCC since $28 \backslash 10 \backslash 1437 \mathrm{H}$ up until the present date, a period exceeds a year and four months. In addition, the company made no effort what so ever to obtain SAMA's written non-objection form prior to assigning the responsibilities of the compliance officer position to Mr. CCC or during his assignment, and when the company was notified by the enteral examination division at SAMA that SAMA has not yet received a formal request to obtain SAMA's non- objection form to assign Mr. CCC, it simply justified that it was an unintentional mistake.

Therefore, it was a negligence from the company's side as its duty is to obtain SAMA's non- objection form prior exceeding the permissible period which is 30 days. The company's negligence is deemed as a failure to comply with the requirements for appointments to senior positions in financial institutions, and also it appears that the company failed to comply with clause (11) from three other aspects:

- Assigning Mr. CCC for a period more than the permissible one.

- Not obtaining SAMA's non- objection form to extend the assignment to another six months before the end of the first six months.

- Exceeding the maximum permissible period without officially appoint him in charge as the compliance officer or occupying the position with another qualified candidate.

Furthermore, the company's justification that it did comply with what it pledged for by assigning Mr. CCC as the compliance officer is not accepted because what pledged for was not assigning one officer to handle the duties and responsibilities of the compliance, rather establishing a compliance department and appointing two officers in it by $13 \backslash 1 \backslash 1436 \mathrm{H}$. In addition, Article (45) of the Finance Companies Control Law stated "The compliance department must have staff and resources commensurate with the business model and size of the finance company", and on $20 \backslash 12 \backslash 1435 \mathrm{H}$, an agreement was reached on the board of directors' meeting which highlighted the importance of hiring another compliance officer to help out Mr. CCC. Hence, the agreement indicates that the company' size and business model requires at least two compliance officers to handle the duties and responsibilities of the compliance department, yet the company did not nominate any candidate to take the charge of the compliance role. Thus, exceeding the specified permissible period without honoring its pledge is a violation of articles (42-45) of the implementing regulation of the Finance Companies Control Law. Because the compliance officer position is not yet occupied by an official one as a request was received on $29 \backslash 05 \backslash 1435 \mathrm{H}$ from the company to change its former request of appointing Mr. CCC to the compliance officer's position into extending his assignment as a compliance officer, then, consequently, that is considered as failure to comply with the legal requirements and a violation of article (41) of the Finance Companies Control Law which states" The finance company shall comply with applicable laws, regulations and instructions and shall take necessary measures and controls to prevent violations."

The accusations of $\mathrm{X}$ company have been affirmed for committing a violation of article (42-45) of the regulation of the Finance Companies Control Law, and a violation of clause (9-11) of the requirements for appointments to senior positions in financial institutions supervised by SAMA. Also, because X company has yet not requested to obtain SAMA's non- objection form to assign or appoint a compliance officer since it was licensed to operate until $20 \backslash 03 \backslash 1437 \mathrm{H}$, despite it was notified twice in the supervisory visits is deemed a failure to comply with the legal requirements, and as a result, the enforcement division are to factor that for an appropriate measurement to be executed against the company. Therefore, the company's undertakings mentioned-above are deemed professional misconducts in accordance with article (76) of the regulations of the Finance Companies Control Law issued by SAMA and a professional misconduct violating corporate governance rules.

\section{Conclusion}

Sustainable accountability of senior management nowadays, especially with the recent collapses of companies who appeared giant and efficient while actually they were fragile, is necessary. It is essential to design a system of governance, in which it will be easily to the board of directors to monitor and ensure managers are fulfilling their responsibilities. Also, board of directors should control the process of appointing executives and assessing their actions. But designing a system, without a regulatory body acting as a disciplinary power for organizations actions, will be worthless. In Saudi Arabia, Saudi Arabian Monetary Agency (SAMA) role is important and it should be strengthen with suitable economic resources and professional expertise to help in organizing the financial market. The benefits of applying good corporate governance rules for encouraging investment and stock market development are crucial in order to improve macroeconomic growth.

\section{References}


Adams, R., Hermalin, B., \& Weisbach, M. (2010). The Role of Boards of Directors in Corporate Governance: A Conceptual Framework and Survey. Journal of Economic Literature, 48(1), 58-107.

Al-Matari, Y., Al-Swidi, A., \& Fadzil, F. (2012). Corporate Governance and Performance of Saudi Arabia Listed Companies. British Journal of Arts and Social Sciences, 9(1), 1-30.

Bernardi, R., \& Lacross, C. (2005). Corporate Transparency: Code of Ethics Disclosures. CPA Journal, 75(4), 34-38.

Clarke, T. (2005). Accounting for Enron: Shareholder Value and Stakeholder Interests. Corporate Governance, 13(5), 598-611.

Coffee, J. (2004). What Caused Enron? A Capsule Social and Economic History of the 1990s, In Clarke, T., (ed.) Theories of Corporate Governance (pp. 333-358). London: Routledge.

Fung, B. (2014). The Demand and Need for Transparency and Disclosure in Corporate Governance. Universal Journal of Management, 2(22), 72-80.

Gibbon, N., Peel, G., Garston, C., \& Bridget, S., (2016). Corporate governance and directors' duties in the UK (England and Wales): Overview, https://uk.practicallaw.thomsonreuters.com/3-597-4626?_lrTS=20170409140346644\&transitionType=Def ault \&contextData $=($ sc.Default $) \&$ firstPage $=$ true $\& b h c p=1$

Güner, B., Malmendier, U., \& Geoffrey, T. (2008). Financial Expertise of Directors. Journal of Financial Economics, 88(2), 323-354.

Heath, J., \& Norman, W. (2004). Stakeholder Theory, Corporate Governance and Public Management: What can the History of State-Run Enterprises Teach us in the Post-Enron Era? Journal of Business Ethics, 53, 247-265.

Isik, O., \& Ince, A. (2016). Board Size, Board Composition and Performance: An Investigation on Turkish Banks. International Business Research, 9(2), 74-84.

Jan, S., \& Sangmi, M. (2016), The Role of Board of Directors in Corporate Governance. Imperial Journal of Interdisciplinary Research, 2(5), 707-715.

Jensen, M. (2002). Value Maximization, Stakeholder Theory, and the Corporate Objective Function. Business Ethics Quarterly, 12(2), 235-256.

Kaplan, S., \& Bernadette, M. (2006). Has the CEO Turnover Changed? Increasingly Performance Sensitive Boards and Increasingly Uneasy CEOs. National Bureau of Economic Research Working Paper 12465 (pp.1-35).

Norman, W. (2004). What can the Stakeholder Theory Learn from Enron? Ethics and Economics, 2(2), 1-12.

Onetto., A. (2007). Agency problems and the board of directors. Butterworths Journal of International Banking and Financial Law, 414-417.

Saudi Arabian Monetary Agency. (1434H). Finance Companies Control Law. Retrieved from http://www.sama.gov.sa/en-US/Finance/FinanceLib/L_EN_ImplementingRegulationoftheFinanceCompanie sControlLaw1.pdf

\section{Copyrights}

Copyright for this article is retained by the author(s), with first publication rights granted to the journal.

This is an open-access article distributed under the terms and conditions of the Creative Commons Attribution license (http://creativecommons.org/licenses/by/4.0/). 